\title{
Determination of epiphyte biomass composition and distribution with a three-dimensional mapping method in a tropical montane forest in northern Thailand
}

\author{
Akira Nakanishi $^{1 *}$, Witchaphart Sungpalee ${ }^{2}$, Kriangsak Sri-ngernyuang ${ }^{3}$ and Mamoru Kanzaki ${ }^{1}$ \\ ${ }^{1}$ Graduate School of Agriculture, Kyoto University, Kitashirakawa Oiwake-cho, Kyoto, 606-8502, Japan \\ ${ }^{2}$ Faculty of Agricultural Production, Maejo University, Chiang Mai, 50290, Thailand \\ ${ }^{3}$ Faculty of Architecture and Environmental Design, Maejo University, Chiang Mai, 50290, Thailand \\ * Corresponding author: nakanishi.akira.64r@st.kyoto-u.ac.jp
}

\begin{abstract}
Epiphytes show complex spatial distribution patterns at various scales, and the description of their distribution patterns, for example, on a tree, is quite difficult. In this study, by using a three-dimensional tree-form mapping method, the tree form of a $47 \mathrm{~m}$-high emergent tree in a tropical montane forest of northern Thailand was measured and reconstructed, and the distribution of epiphytes on the tree was accurately recorded. The epiphytic matter, which consists of epiphytes and canopy humus, on the tree was classified into six types on the basis of its physiognomy, and destructive sampling of the epiphytic matter was performed for each type with three or four replications. The total epiphyte biomass and canopy humus on the tree were $158.2 \mathrm{~kg}$ and $381.3 \mathrm{~kg}$, respectively. Approximately $96 \%$ of the epiphyte biomass was concentrated in the tree crown, above $20 \mathrm{~m}$. The distribution of epiphytic matter types was found to depend on branch diameter, and their spatial distribution from the outer crown to the inner crown was visualized on the three-dimensional reconstructed form of the tree.
\end{abstract}

Key words: canopy humus, emergent tree, epiphytic matter, habitat, Mastixia euonymoides

\section{INTRODUCTION}

During the last few decades, canopy research has been facilitated by the improvement of safe methodology for canopy access, while it had been rarely conducted before because of the inaccessibility to forest canopies and the difficulty to work in them (Lowman 2001, Nadkarni 2001, Lowman 2009). With the enhancement of canopy studies, the ecology of epiphytes has also been revealed gradually.

Epiphytes constitute a major part of the global biodiversity in a forest canopy; vascular epiphytes make up 8-10\% of the total vascular plant diversity, and the proportion has increased to $10-50 \%$ in neotropical forests (Nadkarni et al. 2001, Benzing 2004). Many studies have reported that epiphyte communities show complex spatial distribution patterns at various scales: at different altitudes, in a forest, and on a single tree (Hietz and Briones 1998, Lyons et al. 2000, Nieder et al. 2000, Wolf and Alejandro 2003, Krömer et al. 2007, Zotz and Schultz 2008). Epiphyte species and biomass reach great diversity and abundance in primary tropical montane forests, particularly in cloud forests (Nadkarni 1984, Freiberg and Freiberg 2000, Nadkarni et al. 2004, Gradstein 2008).
Epiphyte biomass comprises roots and green tissues of vascular and nonvascular plants, which constitute a part of the epiphytic matter (EM) on trees with accumulated “canopy humus” (Köhler et al. 2007). In previous studies, canopy humus has been termed as "dead organic matter (DOM)” (Ingram and Nadkarni 1993), “suspended soils” (Wolf 1994, Hsu et al. 2002), and “arboreal soils" (Díaz et al. 2010). In some studies, canopy humus constituted a large proportion of the total EM amount, and epiphyte biomass increased with the accumulation of canopy humus (Ingram and Nadkarni 1993, Nadkarni et al. 2004, Köhler et al. 2007). In a forest ecosystem, EM contributes to the water and nutrient cycles of the whole forest (Nadkarni 1984, Hsu et al. 2002, Nadkarni et al. 2004, Köhler et al. 2007) and the biodiversity of other organisms by providing food and living space (Nadkarni 1994, Benzing 2004, Sillett and Antoine 2004, Gradstein 2008).

However, most studies on epiphytes have been conducted in neotropical forests and considerably only few in the tropical forests in Asia, for example, in a tropical evergreen forest in India (Annaselvam and Parthasarathy 2001), in a moist subtropical forest in Taiwan (Hsu et al. 2002), and in a tropical submontane rainforest in Indonesia 
(Sporn et al. 2010). Therefore, data on epiphyte biomass and canopy humus in Asian tropical forests are extremely scarce.

Epiphyte communities may show quick responses to climate changes such as rise in temperature and changes in precipitation, because they do not have any connection with ground soil and depend completely on atmospheric and arboreal resources (Foster 2001,). For example, the transplant experiment of epiphytes from upper cloud forest to drier climatic conditions with less cloud water ca. $150 \mathrm{~m}$ downslope showed some species had significant higher mortality, lower leaf production, and reduce longevity after one year from transplant event (Nadkarni and Solano 2002). To clarify the effects of climate changes on epiphytes, longterm monitoring of epiphyte communities is necessary (Gradstein 2008). For the precise monitoring, it is important to figure out the distribution of epiphytes within the monitoring area beforehand. Although, the distribution patterns of epiphyte communities was studied various scales as shown before, there are few studies showing the distribution at individual branch unit in detail (Freiberg 1999, Díaz et al. 2010). Since recent impacts of global climate change on forest ecosystems have been remarkable (Foster 2001), a mapping method to know precise and detailed distribution of epiphyte communities needs to be established.

The objectives of this study were to: (1) investigate the composition of EM and estimate the total epiphyte biomass and EM amount on a whole emergent tree; (2) clarify the distribution of EM on the whole emergent tree and visualize it on a three-dimensional reconstructed tree form; and (3) assess the composition and distribution pattern of EM. In addition, a new method mapping the tree architecture was introduced to achieve these objectives in this study. The results were compared with those of the previous studies conducted mainly in tropical montane forests.

\section{MATERIALS AND METHODS}

\section{Study site and study tree}

Field surveys for this study were conducted at the Doi Inthanon Forest Dynamics Plot (15ha, ca. $1700 \mathrm{~m}$ a.s.l.) in Doi Inthanon National Park ( $\left.18^{\circ} 31^{\prime} 34^{\prime \prime} \mathrm{N}, 98^{\circ} 29^{\prime} 39^{\prime \prime} \mathrm{E}\right)$, Chiang Mai province, northern Thailand, from December 2010 to January 2011 and in August 2011. This plot is located in a well-protected and well-developed tropical lower montane forest. The forest canopy varies in height from 15 to $30 \mathrm{~m}$, with emergent trees reaching higher than $50 \mathrm{~m}$ (Kanzaki et al. 2004). In terms of basal area, Fagaceae and Lauraceae were the dominant families. The most abundant species was Mastixia euonymoides (Cornaceae) followed by Quercus eumorpha (Fagaceae), Manglietia garrettii (Magnoliaceae), Calophyllum polyanthum (Guttiferae), Quercus brevicalyx (Fagaceae) and Cryptocarya densiflora (Lauraceae). The average annual rainfall and the average monthly minimum and maximum temperatures at the Royal Project Doi Inthanon Station (1300 $\mathrm{m}$ a.s.l., ca. $5 \mathrm{~km}$ away from the plot, 1993-2006) were $1940 \mathrm{~mm}, 16.4^{\circ} \mathrm{C}$, and $26.3^{\circ} \mathrm{C}$, respectively. The climate is strongly influenced by the monsoon, and a distinct seasonality is recognizable: rainy season (JuneOctober) and dry season (November-May) (Sungpalee et al. 2009). For further details on the study site, refer to previous studies (Hara et al. 2002, Sri-ngernyuang et al. 2003, Kanzaki et al. 2004, Noguchi et al. 2007, Sungpalee et al. 2009).

An emergent tree (height, $47 \mathrm{~m}$; DBH, $150 \mathrm{~cm}$ ), Mastixia euonymoides (Cornaceae), was selected as the study tree, which grew on a low slope. This species is an evergreen and one of the biggest tree species in the montane rainforest, occurring only in the limited border area between Myanmar, Yunnan of China, and Thailand (Zhu 2004). In this study plot, this species is dominant and overlaps the crowns of Fagaceae and Lauraceae trees which are the dominant families (Kanzaki et al. 2004). Therefore, this species was selected as the study tree species. An emergent tree was chosen because it supports a diverse array and high biomass of epiphytes (Díaz et al. 2010). In this study, the study tree was climbed using the single- and double-rope techniques.

\section{Tree-form mapping and estimation of biomass}

To reconstruct the three-dimensional form of the study tree, the tree architecture was mapped in three-dimensional coordinate space by using a hand-held laser range finder (LaserAce ${ }^{\circledR}$ Hypsometer; MDL, Northminster Business Park, York, UK). The bottom of the trunk, all branching points, crooked points, and ends of branches on the study tree (measured point(s), hereafter) were measured from either of five measuring points: one was on the ground, ca. $10 \mathrm{~m}$ from the study tree, and the others were on the study tree. Slope distance, vertical angle, and horizontal angle from the measuring point to the measured point were recorded. Diameter of the stem or branch at each measured point was also measured using a steel tape measure or by reading the stadia hair of the hand-held laser range finder. However, the branching points and crooked points in the tip section of each branch whose diameter was smaller than 5-10 cm were not measured because of the difficulty 
encountered in their accurate measurement with the laser range finder. Each portion between adjacent measured points was considered as a segment, which had a cylindrical shape like the frustum of a circular cone. A total of 543 measured points were formed into three-dimensional coordinates, following which the tree form was reconstructed using GroIMP (a free three-dimensional modeling platform; for more details on GroIMP, visit http://sourceforge. net/projects/groimp/). In this study, the crown projection area was considered as the area of the plane made of the measured points which were located horizontally outer edge of the tree crown. These measured points were selected on the three-dimensional reconstructed tree form, and then the crown projection area was calculated.

To measure the wood density and estimate the surface area and biomass of branch tip sections, a branch was sampled from the middle layer of the tree crown in January 2011. The branch sample was divided into eight sections, and the length and diameter of all shoots and twigs included in each section were measured to calculate the total surface area and volume in each section. Fresh weight of all the leaves and seeds in each section was also measured. Twelve subsamples of the wood portion (for measuring the wood density) and a 50-g subsample each of leaves and seeds were stored from the branch sample. All the subsamples were oven dried at $90^{\circ} \mathrm{C}$ for $3-5 \mathrm{~d}$, following which dry weight was measured. Then, power-function allometry models of surface area and biomass to the branch base diameter were created. The dry-wood biomass of the segments was calculated with two wood density values: (1) $0.45 \mathrm{~g} \mathrm{~cm}^{-3}$ (obtained in this study) for segments with the branch base diameter less than $10 \mathrm{~cm}$ and (2) $0.49 \mathrm{~g} \mathrm{~cm}^{-3}$, an averaged wood density of $M$. euonymoides (Sungpalee et al. 2009), for ones with the branch base diameter not less than $10 \mathrm{~cm}$. For branch tip sections, branch biomass, including that of leaves and seeds, was estimated using allometric equations. The total aboveground biomass of the study tree was calculated by adding the biomass of all the segments and branch tip sections.

\section{Epiphyte-community mapping}

In this study, EM was classified into six EM types on the basis of the differences in physiognomy among epiphyte communities (Fig. 1): two types on the main stem, i.e., lower stem (LS) and upper stem (US), and four types on the branches, i.e., sparse bryophytes (SB), bryophyte mat (BM), vascular-plant mat (VM), and orchid mat (OM). On the main stem, LS and US were distinguished by the amount of bryophytes, with US having a larger amount of bryophytes than LS. On the branches, first, EM was divided depending on the presence or absence of epiphytic mat. EM without epiphytic mat was classified as SB, which had a small amount of bryophytes and sparsely occurring lichens. EM with epiphytic mat was distinguished by the trait of the mat. BM consisted mainly of bryophytes and VM and OM had a large amount of vascular epiphytes and thick canopy humus layer, with OM especially having a large amount of orchids. While a lot of studies on epiphyte biomass estimation classified EM by the substrate type, i.e., the position on the tree such as Johansson zone (Johansson 1974) (Freiberg and Freiberg 2000, Hsu et al. 2002, Nadkarni et al. 2004, Köhler et al. 2007), the EM was classified by the physiognomy because the several kinds of EM types often occur in the similar position on an individual tree. The visual survey for epiphyte biomass estimation was conducted in several previous studies; by assessing the number of leaves, fronds or rosettes of epiphytes, or the lengths thereof (Wolf et al. 2009) and by counting the number of 10-kg unit of epiphyte biomass (Díaz et al. 2010).

Considering the study of Ando $\mathrm{N}$ et al. (unpublished data), which investigated the species compositions of canopy plants on some canopy and emergent trees, including the study tree of this study, in a 15-ha plot, the epiphyte communities on the study tree were classified into ten community types. LS was mainly included in a bryophyte community, which was characterized by Neckeropsis exserta, Neckera himalayana, Fissidens anomalus, Trachypus bicolor. US was mainly included in two bryophyte communities: one was the same as that of LS, and the other was characterized by Leucobryum javense, Oedicladium rufescens, Symphyodon leiocarpus, and Trachypus bicolor. SB and BM were mainly included in two bryophyte communities: one was the same as the latter one of US, and the other was characterized by Pterobryopsis divergens and Macromitrium sulcatum. VM was mainly included in two bryophyte communities, similar to SB and BM, and a vascular-epiphyte community, which was characterized by deciduous herbaceous plants (Anisadenia saxatilis and Sonerila violaefolia), deciduous ferns (Oleandra wallichii), and evergreen ferns (Elaphoglossum marginatum and Hymenophyllum polyanthos). OM was mainly included in two bryophyte communities, similar to SB and BM, and two vascularepiphyte communities, which were characterized by deciduous woody plants (Agapetes lobbii, Agapetes hosseana, and Rhododendron veitchianum), evergreen ferns (Crypsinus rhynchophyllus, Elaphoglossum marginatum, and Hymenophyllum polyanthos), and orchids (Coelogyne longipes and Otochilus albus). Akiyama et al. (2011) listed all of the bryophyte species founded in the study of Ando et 

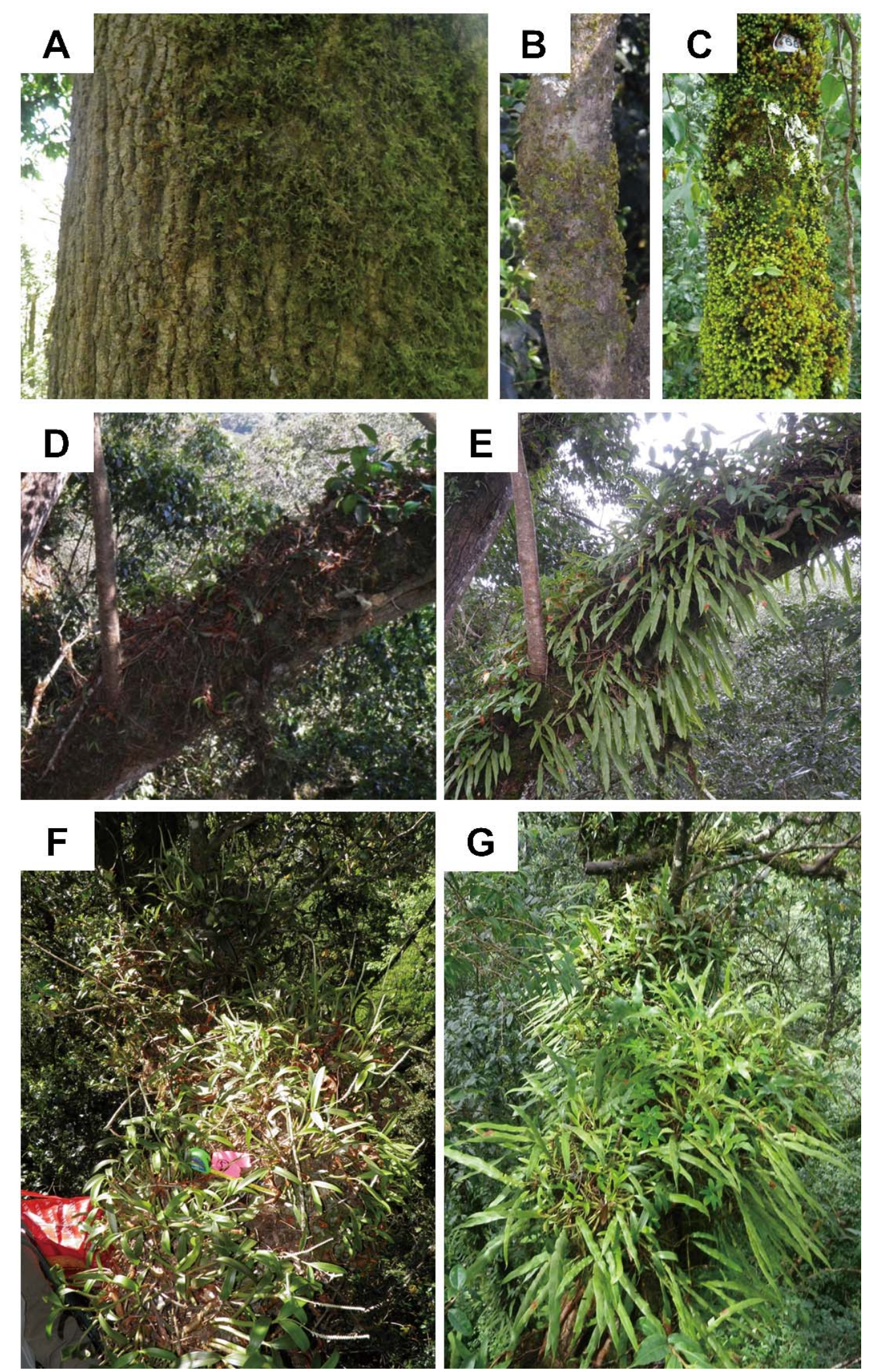

Fig. 1. Pictures showing the physiognomic characteristics of each EM type: (A) main-stem types (LS and US), (B) SB, (C) BM, (D) VM in the dry season, (E) VM in the rainy season, (F) OM in the dry season, and (G) OM in the rainy season. (D) and (F) show the same portion as (E) and (G), respectively. LS: Lower Stem, US: Upper Stem, SB: Sparse Bryophytes, BM: Bryophyte Mat, Vascular-plant Mat, OM: Orchid Mat. 
al.. EM type and coverage (\%) on each segment were recorded using binoculars in the dry season. The recorded EM type on each segment was described on the threedimensional reconstructed tree form.

\section{Sampling of EM}

To assess the composition of each EM type and estimate the total epiphyte biomass on the study tree, sampling of each EM type was conducted in both the dry and rainy seasons (January and August, respectively). SB was sampled only from the branch sample (see previous section). For SB sampling, all EM was removed from 13 cylindrical plots randomly located on the sampled branch. EM coverage, plot length, and branch diameters at both the ends were recorded for each plot. Power-function models of EM cover area and amount to the branch base diameter were created for the estimation of branch tip sections, in a similar way as the abovementioned allometry models for the study tree.

Sampling plots for the other EM types were randomly located in the accessible segments. The number of EM sampling plots was three (two in the dry season and one in the rainy season) for each main-stem type and four (one in the dry season and three in the rainy season) for each branch type. In each sampling plot in the main-stem segment, EM was removed from a square plot (each side, ca. $20 \mathrm{~cm}$ ), and the length of each side of the square plot was recorded. In each sampling plot in the branch segment, EM was removed from the cylindrical band (width, 8-17 cm) encircling the segment, and the branch circumference and width of the band were recorded. Lichens were neglected in this study because they were negligible in amount and difficult to remove from the bark. Hemiepiphytic trees and vines, which were rooted in the ground and hence extended from the top to the base of the tree, were also neglected because their large mass could not be removed. For each sampling plot, EM was removed as completely as possible and placed in a plastic bag.

All EM samples were taken to the field laboratory and subsequently separated into the following components: (1) bryophytes, (2) pteridophytes (fronds), (3) non-orchid spermatophytes (shoots and flowers, excluding orchids), (4) orchids (leaves, bulbs, and flowers), (5) roots and rhizomes (roots of spermatophytes, including orchids, and rhizomes of pteridophytes), and (6) canopy humus (partly and highly decomposed organic matter such as dead epiphytes, trapped litter, and partially decomposed tree bark). In this study, it was assumed that vascular epiphytes comprised pteridophytes, non-orchid spermatophytes, and orchids; green tissues comprised bryophytes and vascular epiphytes; and epiphyte biomass consisted of green tissues and roots and rhizomes. The components of each EM sample were oven dried to a constant weight at $90^{\circ} \mathrm{C}$ for $24-96 \mathrm{~h}$, following which dry weight was measured. For each EM type, the amount of each component per unit EM cover area was calculated from the average of EM samples.

\section{Estimation of EM cover area and EM amount}

EM cover area in each segment was calculated by multiplying EM coverage with the surface area of the segment. EM amount in each segment was calculated by multiplying the EM cover area with the amount of each component per unit EM cover area for the EM type. In branch tip sections, the EM cover area and amount were estimated using the allometric equations, as mentioned above. The total EM cover area and amount on the study tree were calculated by adding the values of all the segments and branch tip sections.

\section{Data analysis}

The regression analysis for all allometric equations for estimation of branch biomass and EM cover area and amount in branch tip sections were done after linearization by taking logarithms of both sides of the equations.

\section{RESULTS}

\section{Three-dimensional reconstructed tree form}

The three-dimensional reconstructed form of the study tree is shown in Fig. 2. Colors of the segments indicate the EM type occurring in the segments. The details of branch tip sections were omitted from the reconstructed tree form. The tree crown was formed above the height of ca. $20 \mathrm{~m}$ of the study tree, and in particular, many branches were developed above ca. $30 \mathrm{~m}$. The crown projection area was $409.4 \mathrm{~m}^{2}$.

The allometric equations for branch, leaves, and seeds biomass ( $w_{b}[\mathrm{~g}], w_{l}[\mathrm{~g}]$, and $w_{s}$ [g], respectively) to the branch-base diameter $\left(D_{\text {Base }}[\mathrm{cm}]\right)$ on branch tip sections were established as:

$$
\begin{aligned}
& w_{b}=14.476 \times D_{\text {Base }}^{3.163} \\
& w_{l}=14.896 \times D_{\text {Base }}^{2.425} \\
& w_{s}=1.737 \times D_{\text {Base }}^{2.687}
\end{aligned}
$$

of which the $R^{2}$ values were $0.99,0.98$, and 0.99 , respectively $(p<0.001)$. 
The total aboveground biomass of the study tree was estimated to be $31.9 \times 10^{3} \mathrm{~kg}$. The wood, leaf, and seed biomass represented $97.9 \%, 1.8 \%$, and $0.4 \%$ of the total biomass, respectively.

\section{Composition of each EM type}

In this study, the pteridophyte and non-orchid spermatophyte components of EM samples included deciduous species. Since they defoliated in the dry season, the pteridophytes and non-orchid spermatophytes of each EM type, especially VM and OM, varied drastically in their

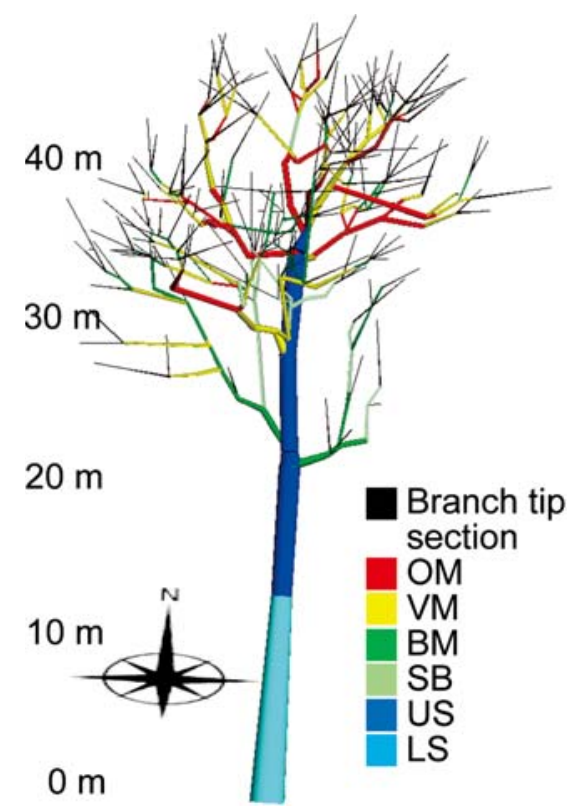

Fig. 2. Three-dimensional reconstructed form of the emergent study tree. The distribution of EM types is shown, but the EM coverage on each segment is not reflected. The details of branch tip sections are omitted. amounts according to the seasons; the dry-season EM samples did not include these plant types. Therefore, in this study, only the EM sampling data of the rainy season were used for pteridophytes and non-orchid spermatophytes.

The amounts of components greatly differed among the EM types (Table 1). Within each EM type, the amounts of some components varied widely among the sampling plots. Regarding the main-stem types, LS and US mainly comprised bryophytes and the other components were very few or absent. The amounts of components of LS and US were smaller than those of branch types, excluding SB. Regarding branch types, SB comprised only a very small amount of bryophytes. BM, VM, and OM, which had thick epiphytic mats, consisted of all kinds of components. BM consisted of mainly bryophytes and had the largest amount of bryophytes of all the EM types. Although VM and OM had larger amounts of vascular epiphytes and roots and rhizomes than BM, they comprised even much larger amount of canopy humus than BM (3.9 times and 3.2 times as much canopy humus as epiphyte biomass, respectively). There was a tendency that the amount of bryophytes decreased and those of pteridophytes, orchids, roots and rhizomes, and canopy humus increased in the order BM, $\mathrm{VM}$, and OM.

\section{EM cover area and epiphyte biomass}

The total EM cover area on the study tree was $458.6 \mathrm{~m}^{2}$. Much of the surface of the study tree was not used by epiphyte communities; the total EM cover area was equivalent to $16.7 \%$ of the surface area of the study tree. SB composed a large proportion of the total EM cover area (64.5\%), and the other EM types made up similar proportions of the remaining EM cover area (6.5\%, 3.9\%, $7.7 \%$, $8.9 \%$, and $8.6 \%$ for LS, US, BM, VM, and OM,

Table 1. Amounts of components of each epiphyte matter (EM) type per unit EM cover area $\left(\mathrm{g} \mathrm{m}^{-2}\right)$. Values indicate average \pm SE. Numbers in parenthesis are the numbers of analyzed samples.

\begin{tabular}{|c|c|c|c|c|c|c|}
\hline \multirow{3}{*}{$\begin{array}{l}\text { EM components } \\
\left(\mathrm{g} \mathrm{m}^{-2}\right)\end{array}$} & \multicolumn{6}{|l|}{ EM type } \\
\hline & \multicolumn{3}{|c|}{ Main stem } & \multicolumn{3}{|c|}{ Branch } \\
\hline & LS & US & $\mathrm{SB}^{\mathrm{a}}$ & $\mathrm{BM}$ & VM & $\mathrm{OM}$ \\
\hline Bryophytes & $110.7 \pm 10.9(3)$ & $180.4 \pm 1.7(3)$ & $10.8 \pm 1.8$ & $327.5 \pm 163.7(4)$ & $225.6 \pm 89.3(4)$ & $190.3 \pm 60.6(4)$ \\
\hline Pteridophytes $^{\mathrm{b}}$ & $0(1)$ & $0(1)$ & 0 & $0.1 \pm 0.1(3)$ & $93.5 \pm 36.5(3)$ & $153.4 \pm 64.2(3)$ \\
\hline Non-orchid spermatophytes ${ }^{b}$ & $0.2(1)$ & $1.4(1)$ & 0 & $0.2 \pm 0.2(3)$ & $36.0 \pm 14.2(3)$ & $26.6 \pm 15.1(3)$ \\
\hline Orchids & $0(3)$ & $0(3)$ & 0 & $0.7 \pm 0.7(4)$ & $8.7 \pm 8.7(4)$ & $539.8 \pm 296.1(4)$ \\
\hline Roots and rhizomes & $9.5 \pm 9.5(3)$ & $2.0 \pm 2.0(3)$ & 0 & $21.8 \pm 14.4(4)$ & $552.3 \pm 153.4(4)$ & $967.0 \pm 166.6(4)$ \\
\hline Canopy humus & $8.4 \pm 8.4(3)$ & $1.0 \pm 1.0(3)$ & 0 & $21.6 \pm 14.3(4)$ & $3590.3 \pm 542.3(4)$ & $5964.5 \pm 1428.9(4)$ \\
\hline
\end{tabular}

EM type: $L S$, lower stem; $U S$, upper stem; $S B$, sparse bryophytes; $B M$, bryophyte mat; $V M$, vascular mat; $O M$, orchid mat.

${ }^{\mathrm{a}}$ Values calculated from 13 samples on a branch sample of the dry season.

${ }^{\mathrm{b}}$ Values calculated only from the EM sampling data of the rainy season. 


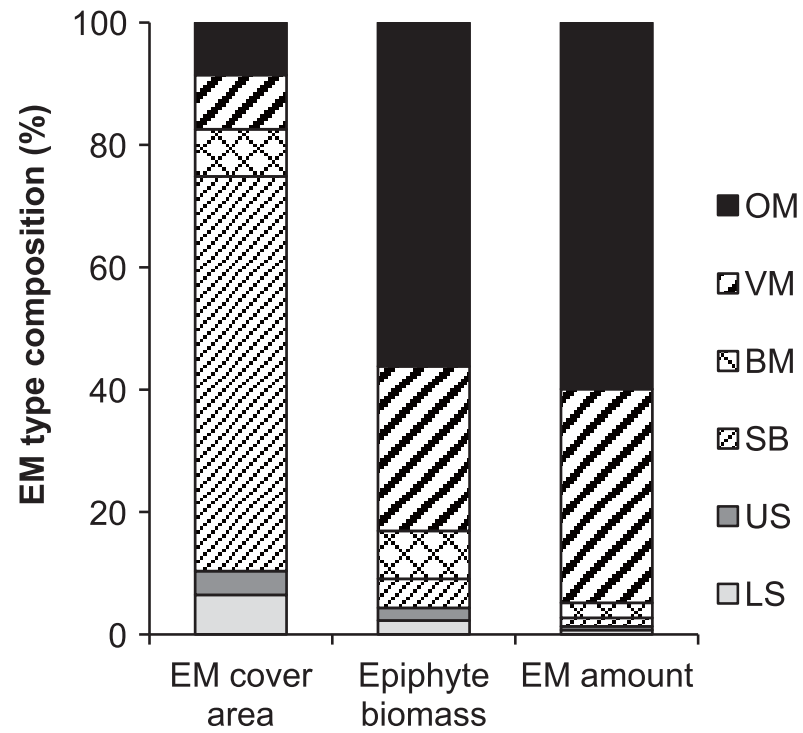

Fig. 3. The EM type compositions of the total EM cover area, epiphyte biomass, and EM amount on the emergent study tree.

respectively) (Fig. 3).

The total epiphyte biomass and EM amount on the study tree were estimated to be $158.2 \mathrm{~kg}$ and $539.6 \mathrm{~kg}$, respectively (Table 2). The EM amount per crown projection area was $13.2 \mathrm{Mg} \mathrm{ha}^{-1}$. The majority of the total EM amount was canopy humus (70.7\%). Green tissues and roots and rhizomes made up similar amounts (14.1\% and $15.2 \%$, respectively). Regarding the total green tissue biomass, more than $50 \%$ was constituted by bryophytes, followed by orchids, which constituted a large proportion, and pteridophytes and non-orchid spermatophytes made up a very small proportion. The total epiphyte biomass and EM amount constituted less than $2 \%$ of the total aboveground biomass of the tree, but epiphytic green tissues were equivalent to $12 \%$ of the total aboveground green tissues, which was the sum of the leaves of the study tree and epiphytic green tissues.

With regard to the composition according to each EM type, VM and OM, which had large amounts of vascular epiphytes and roots and rhizomes, highly contributed to the total epiphyte biomass ( $26.9 \%$ and $56.2 \%$, respectively) and even more to the total EM amount by the thick canopy humus layer (34.9\% and 59.9\%, respectively) (Fig. 3), although SB constituted the major proportion of the total EM cover area. The other EM types made up a very small proportion of the total epiphyte biomass and EM amount.

\section{Distribution of EM}

Most of the EM cover area and epiphyte biomass concentrated above the height of ca. $20 \mathrm{~m}$ of the study tree, i.e., in the tree crown ( $90.9 \%$ and $96.4 \%$, respectively)
Table 2. Total amounts of EM and its components on the single study tree. Each value was calculated from those given in Table 1.

\begin{tabular}{lr}
\hline EM components & Total amount $(\mathrm{kg})$ \\
\hline Epiphytes & \\
Green tissues & \\
Bryophytes & 42.2 \\
Pteridophytes & 9.8 \\
Non-orchid spermatophytes & 2.5 \\
Orchids & 21.6 \\
Total green tissues biomass & 76.2 \\
Roots and rhizomes & 82.0 \\
Total epiphyte biomass & 158.2 \\
Canopy humus & 381.3 \\
Total EM & 539.6 \\
\hline
\end{tabular}

(Fig. 4). In particular, the EM cover area was quite large above the height of $30 \mathrm{~m}$, where many branches developed, and epiphyte biomass was abundant in the 30-40 m range of height, where thick branches developed.

Although the EM coverage increased on the branch segments with the base diameters up to class IV, it was constant on around $50 \%$ of the branch segments with the base diameters above class IV, i.e., branch segment base diameter more than $4 \mathrm{~cm}$ (Fig. 5). The available habitat for epiphytes on a branch is ca. $50 \%$ of the total surface area because EM cannot cover the lower side of most branch segments; therefore, most of the surface area available as habitat for epiphytes was covered on the segments with large base diameter classes. There was no EM on the segments with class I base diameter, whose surface area made up more than $50 \%$ of the total surface area. The composition of EM also differed among the segment base diameter classes: as the segment base diameter increased, the main EM type changed in order from SB to BM, VM, and $\mathrm{OM}$.

\section{DISCUSSION}

The amounts of components greatly differed among the EM types (Table 1). BM, VM, and OM, which had thick epiphytic mats, constituted a large proportion of the EM. VM and OM were especially made up of not only a relatively large amount of vascular epiphytes but also a much greater amount of roots and rhizomes and canopy humus. This pattern indicates that the accumulation of canopy humus is essential for the development of vascular epiphyte communities, since humus provides the space for the development of roots or rhizomes and the nutrients and 

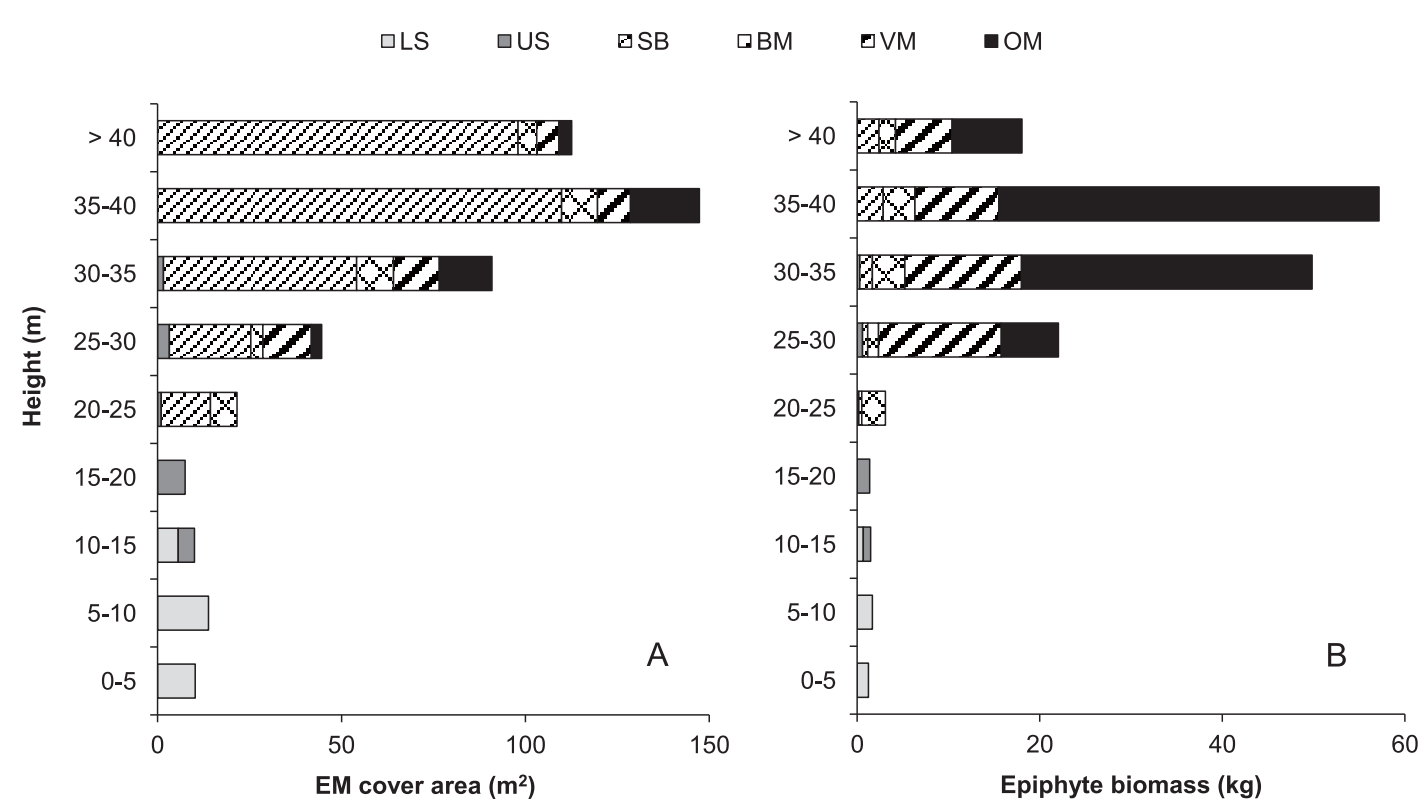

Fig. 4. Vertical distributions of epiphyte communities on the emergent study tree with regard to (A) EM cover area and (B) epiphyte biomass.

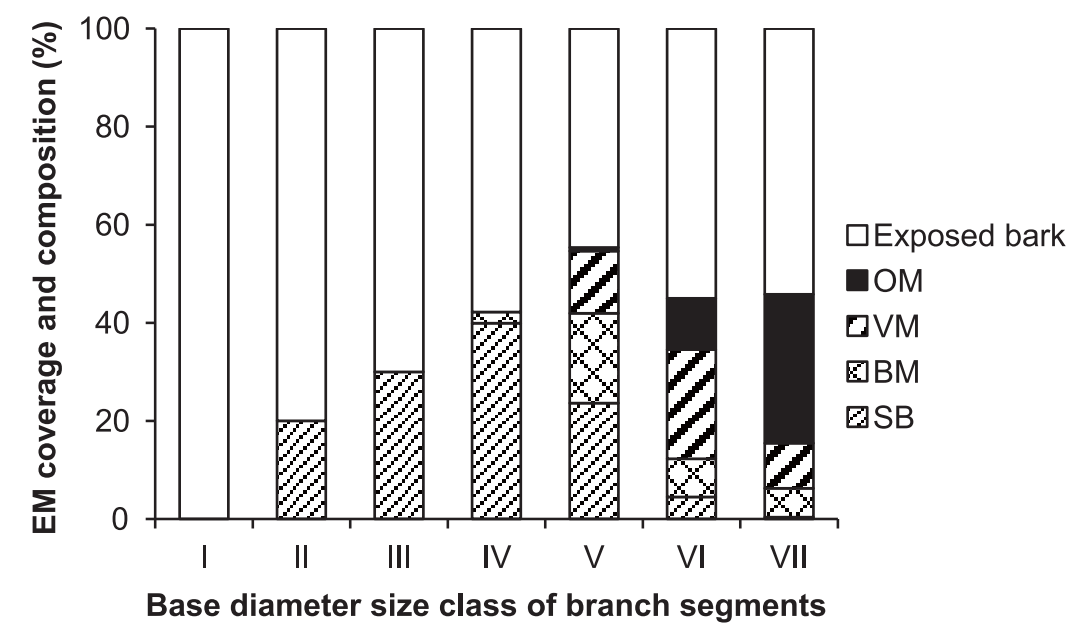

Fig. 5. EM coverage and composition on branch segments with different base diameter classes (I-VII). Exposed bark refers to the portion without EM. Class $\mathrm{I}=<1 \mathrm{~cm}\left(1380.5 \mathrm{~m}^{2}\right)$, Class II $=1-2 \mathrm{~cm}\left(335.9 \mathrm{~m}^{2}\right)$, Class III $=2-4 \mathrm{~cm}$ $\left(160.3 \mathrm{~m}^{2}\right)$, Class IV $=4-8 \mathrm{~cm}\left(171.4 \mathrm{~m}^{2}\right)$, Class $\mathrm{V}=8-16 \mathrm{~cm}\left(38.2 \mathrm{~m}^{2}\right)$, Class $\mathrm{VI}=16-32 \mathrm{~cm}\left(52.0 \mathrm{~m}^{2}\right)$, and Class VII $=>32 \mathrm{~cm}\left(51.3 \mathrm{~m}^{2}\right)$. Values in parentheses indicate segment area of the total branch surface area.

water required for the growth of vascular epiphytes. Despite the relatively large diameter and high age of the main stem, the amounts of components of the main-stem types were smaller than those of branch types, excluding SB. This is because the accumulation of canopy humus on the steep surface of the main stem is difficult, and therefore, the spread of vascular epiphytes is inhibited.

The number of EM sampling plots on the single tree in this study (a branch sample and 18 plots in total) was in the same range as that in similar previous studies (ca. 4-24 plots) (Nadkarni 1984, Ingram and Nadkarni 1993, Freiberg and Freiberg 2000, Köhler et al. 2007, Gehrig-Downie et al. 2011). Further EM samplings may be needed for more precise estimation, but it can cause excessive disturbance in epiphyte communities. Some studies in neotropical montane forests have reported slow regeneration of epiphyte diversity (Nadkarni 2001, Holz and Gradstein 2005, Gradstein 2008). Gradstein (2008) reported that strong decline of epiphyte species richness following forest disturbance occurred in areas that had a moderately seasonal, humid climate. A similar phenomenon occurred in EM sampling plots at microscale. Therefore, the number of 
EM sampling plots should not be increased without considering, in order, the negative impact on epiphyte diversity and ecosystem.

The total EM amount $(539.6 \mathrm{~kg}$ ) on the single tree in this study (at the elevation of ca. $1700 \mathrm{~m}$ a.s.l.) was much greater than on trees surveyed in other tropical montane forests, e.g., $141.9 \mathrm{~kg}$ in a neotropical elfin forest in Costa Rica (1600-1800 m a.s.l.) (Nadkarni 1984) and 140.9 kg in a lower montane cloud forest in Costa Rica (1490 m a.s.l.) (Köhler et al. 2007) (DBH: $>70 \mathrm{~cm}$ and $>60 \mathrm{~cm}$ in neotropical elfin forest and lower montane cloud forest, respectively), although the studies also focused on relatively small trees. In this study, the total EM amount was constituted mainly by canopy humus (ca. $70 \%$ ), followed by roots and rhizomes (ca. 15\%), and the other components constituted very small proportions. Compared with the previous studies, this study showed an EM composition pattern very similar to that reported in the neotropical lower montane cloud forests in Costa Rica (Ingram and Nadkarni 1993, Nadkarni et al. 2004), although Köhler et al. (2007) reported a different pattern in a lower montane cloud forest in Costa Rica. In addition, the pattern observed in this study differed from that in secondary forests, which were characterized by a very high proportion (over $90 \%$ ) of bryophytes or non-vascular epiphytes (Nadkarni et al. 2004, Köhler et al. 2007). Regarding the EM types, VM and OM made up over $90 \%$ of the total EM amount. This indicates that the epiphytic mat with a large amount of vascular epiphytes and their roots and rhizomes contributes greatly to the abundance of epiphyte biomass and that canopy humus included in the epiphytic mat can be one of the indices of the abundance of epiphytes.

Although epiphytes constituted less than $2 \%$ of the total aboveground biomass of the tree, the proportion of epiphytic green tissues increased to ca. $12 \%$ only in the aboveground green tissues (Table 2). This may be one of the reasons that epiphytes contribute to photosynthesis in forest ecosystems. While the epiphyte biomass estimated in this study comprised that of only holoepiphytes excluding lichens, i.e., hemiepiphytic trees and vines were not included, the proportion of epiphytes including them in the total aboveground biomass and green tissues will be more or less larger. In this study, however, the proportion of epiphytic green tissues in the total aboveground green tissues was smaller than that observed in the previous studies: ca. $30 \%$ in a neotropical elfin forest in Costa Rica (1600-1800 m a.s.l.) (Nadkarni 1984) and 29-59\% including hemiepiphytic trees and vines in a coastal temperate rainforest in southern Chile (Díaz et al. 2010).

This is one of the very few studies that sampled EM both in the dry and rainy seasons. The physiognomy of VM and OM differed greatly between the dry and rainy seasons (Fig. 1). In fact, the EM samples of VM and OM in the dry season had much smaller amounts of pteridophytes and non-orchid spermatophytes than those in the rainy season. This was because the samples included deciduous pteridophytes and non-orchid spermatophytes, which had shed their leaves in the dry season. Therefore, the epiphyte biomass in the rainy season should be examined to clarify the maximum epiphyte biomass in areas where the climate is influenced by seasonal monsoon.

In this study, most of the EM cover area and epiphyte biomass were concentrated in the crown of the emergent tree (Fig. 2; Fig. 4). This was because the tree crown, which had many branches, provided epiphyte communities with a large space as their habitat. This suggests that tree crown is the most important habitat for epiphyte communities.

Although EM coverage increased as the segment base diameter increased among the branch segments with relatively small base diameters (up to class IV), most of the surface area available as habitat for epiphytes was occupied on the branch segments with larger base diameters (above class IV) (Fig. 5). In addition, the EM type changed in order from SB to BM, VM, and OM, with increase in the branch segment base diameter. This pattern reflects the facts that bryophytes are early colonizers on young (small) branches while most vascular epiphytes may need canopy humus, bryophytes, and/or more time to establish and that canopy humus also needs much more time to accumulate (Ingram and Nadkarni 1993, Freiberg and Freiberg 2000, Köhler et al. 2007). Another reason for this pattern is that small branches cannot support vascular epiphytes and canopy humus, and consequently, these components occur on large branches with high supporting capacity. In the tree crown, since the branch diameters decrease from the inner main branching points toward the outer branches, the segments with class VII diameters were equivalent to the inner branches and the diameter class changed in order from class VII to class I toward the outer branches. Therefore, the distribution of EM types according to branch diameter was seen in the crown of the three-dimensional reconstructed tree form (Fig. 2). A similar pattern of gradual change of the main components of EM from vascular epiphytes, roots and rhizomes, and canopy humus on the inner branches to bryophytes toward the middle and outer branches has been reported for dominant trees in some old-growth neotropical montane forests (Nadkarni 1984, Ingram and Nadkarni 1993, Freiberg and Freiberg 2000, Köhler et al. 2007).

In this study, the amount and composition of EM and the distribution of EM types on a single emergent tree were 
clarified using a new three-dimensional mapping method. In addition, this method contributed to the relatively precise estimation of large-tree biomass and visualization of the distribution of EM. This method will be useful for longterm monitoring of epiphyte community dynamics. Incorporation of other factors such as microclimate conditions will facilitate more detailed understanding of the distribution of epiphyte communities visually. It also becomes possible to estimate and assess the composition and distribution of epiphyte biomass on other scales like a stand by investigating all trees in a certain area by using this method.

ACKNOWLEDGMENTS We are very grateful to Mr. Tsutomu Irie (a professional arborist) for technical instructions on tree climbing and assistance in field survey; Mr. Jakpun for vital support in carrying out the field survey; the staff members at Doi Inthanon National Park for providing perfect research conditions at the study site; and National Research Council of Thailand (NRCT) for the kind permission to conduct research in Doi Inthanon National Park (Registration no. 83/52). This study was supported by Grants-in-Aid for Scientific Research (B) (No. 20405008, 22405023, \& 24255007) to MK from the Ministry of Education, Culture, Sports, Science and Technology of Japan.

\section{REFERENCE}

Akiyama H, Furuki T, Sri-ngernyuang K, Kanzaki M. 2011. Alphabetical list of bryophytes occurring in a 15 ha longterm monitoring plot at Doi Inthanon, Northern Thailand. Bryological Research 10: 153-164.

Annaselvam J, Parthasarathy N. 2001. Diversity and distribution of herbaceous vascular epiphytes in a tropical evergreen forest at Varagalaiar, Western Ghats, India. Biodiversity and Conservation 10: 317-329.

Benzing DH. 2004. Vascular epiphytes. In: Lowman MD, Rinker HB (eds) Forest canopies. Academic Press, New York, New York. 175-223.

Díaz IA, Sieving KE, Peña-Foxon ME, Larraín J, Armesto JJ. 2010. Epiphyte diversity and biomass loads of canopy emergent trees in Chilean temperate rain forests: a neglected functional component. Forest Ecology and Management 259: 1490-1501.

Foster P. 2001. The potential negative impacts of global climate change on tropical montane cloud forests. Earth-Science Reviews 55: 73-106.

Freiberg M. 1999. The vascular epiphytes on a Virola michelii tree (Myristicaceae) in French Guiana. Ecotropica 5: 75-81.

Freiberg M, Freiberg E. 2000. Epiphyte diversity and biomass in the canopy of lowland and montane forests in Ecuador. Journal of Tropical Ecology 16: 673-688.

Gehrig-Downie C, Obregón A, Bendix J, Gradstein SR. 2011. Epiphyte biomass and canopy microclimate in the tropical lowland cloud forest of French Guiana. Biotropica 43: 591596.

Gradstein SR. 2008. Epiphytes of tropical montane forests impact of deforestation and climate change. In: Gradstein SR, Homeier J, Gansert D (eds) The tropical mountain forest: Patterns and processes in a biodiversity hotspot. University of Göttingen, Göttingen, Germany. 51-65.

Hara M, Kanzaki M, Mizuno T, Noguchi H, Sri-Ngernyuang K, Teejuntuk S, Sungpalee C, Ohkubo T, Yamakura T, Sahunalu P, Dhanmanonda P, Bunyavejchewin S. 2002. The floristic composition of tropical montane forest in Doi Inthanon National Park, Northern Thailand, with special reference to its phytogeographical relation with montane forests in tropical Asia. Natural History Research 7: 1-17.

Hietz P, Briones O. 1998. Correlation between water relations and within-canopy distribution of epiphytic ferns in a Mexican cloud forest. Oecologia 114: 305-316.

Holz I, Gradstein SR. 2005. Cryptogamic epiphytes in primary and recovering upper montane oak forests of Costa Rica - species richness, community composition and ecology. Plant Ecology 178: 89-109.

Hsu C-C, Horng F-W, Kuo C-M. 2002. Epiphyte biomass and nutrient capital of a moist subtropical forest in north-eastern Taiwan. Journal of Tropical Ecology 18: 659-670.

Ingram SW, Nadkarni NM. 1993. Composition and distribution of epiphytic organic matter in a neotropical cloud forest, Costa Rica. Biotropica 25: 370-383.

Johansson D. 1974. Ecology of vascular epiphytes in West African rain forest. Acta Phytogeographica Suedica 59: 1-136.

Kanzaki M, Hara M, Yamakura T, Ohkubo T, Tamura MN, Sringernyuang K, Sahunalu P, Teejuntuk S, Bunyavejchewin S. 2004. Doi Inthanon Forest Dynamics Plot, Thailand. In: Losos EC, Leigh EG Jr. (eds) Tropical forest diversity and dynamism: Findings from a large-scale plot network. University of Chicago Press, Chicago, U.S.A.. 474-481.

Köhler L, Tobón C, Frumau KFA, Bruijnzeel LA(S). 2007. Biomass and water storage dynamics of epiphytes in oldgrowth and secondary montane cloud forest stands in Costa Rica. Plant Ecology 193: 171-184.

Krömer T, Kessler M, Gradstein SR. 2007. Vertical stratification of vascular epiphytes in submontane and montane forest of the Bolivian Andes: the importance of the understory. Plant Ecology 189: 261-278.

Lowman, MD. 2001 Plants in the forest canopy: some reflections on current research and future direction. Plant Ecology 153: 39-50.

Lowman MD. 2009. Canopy research in the twenty-first century: a review of arboreal ecology. Tropical Ecology 50: 125-136.

Lyons B, Nadkarni NM, North MP. 2000. Spatial distribution and succession of epiphytes on Tsuga heterophylla (western hemlock) in an old-growth Douglas-fir forest. Canadian Journal of Botany 78: 957-968. 
Nadkarni NM. 1984. Epiphyte biomass and nutrient capital of a neotropical elfin forest. Biotropica 16: 249-256.

Nadkarni NM. 1994. Diversity of species and interactions in the upper tree canopy of forest ecosystems. Integrative and Comparative Biology 34: 70-78.

Nadkarni NM. 2001. Enhancement of forest canopy research, education, and conservation in the new millennium. Plant Ecology 153: 361-367.

Nadkarni NM, Solano R. 2002. Potential effects of climate change on canopy communities in a tropical cloud forest: an experimental approach. Oecologia 131: 580-586.

Nadkarni NM, Merwin MC, Nieder J. 2001. Forest canopies, plant diversity. Encyclopedia of Biodiversity 3: 27-40.

Nadkarni NM, Schaefer D, Matelson TJ, Solano R. 2004 Biomass and nutrient pools of canopy and terrestrial components in a primary and a secondary montane cloud forest, Costa Rica. Forest Ecology and Management 198: 223-236.

Nieder J, Engwald S, Klawun M, Barthlott W. 2000. Spatial distribution of vascular epiphytes (including hemiepiphytes) in a lowland Amazonian rain forest (Surumoni Crane Plot) of southern Venezuela. Biotropica 32: 385-396.

Noguchi H, Itoh A, Mizuno T, Sri-ngernyuang K, Kanzaki M, Teejuntuk S, Sungpalee W, Hara M, Ohkubo T, Sahunalu P, Dhanmmanonda P, Yamakura T. 2007. Habitat divergence in sympatric Fagaceae tree species of a tropical montane forest in northern Thailand. Journal of Tropical Ecology 23: 549558.

Sillett SC, Antoine ME. 2004. Lichens and bryophytes in forest canopies. In: Lowman MD, Rinker HB (eds) Forest canopies. Academic Press, New York, New York. 151-174.

Sporn SG, Bos MM, Kessler M, Gradstein SR. 2010. Vertical distribution of epiphytic bryophytes in an Indonesian rainforest. Biodiversity and Conservation 19: 745-760.

Sri-Ngernyuang K, Kanzaki M, Mizuno T, Noguchi H, Teejuntuk S, Sungpalee C, Hara M, Yamakura T, Sahunalu P, Dhanmanonda P, Bunyavejchewin S. 2003. Habitat differentiation of Lauraceae species in a tropical lower montane forest in northern Thailand. Ecological Research 18: $1-14$.

Sungpalee W, Itoh A, Kanzaki M, Sri-ngernyuang K, Noguchi H, Mizuno T, Teejuntuk S, Hara M, Chai-udom K, Ohkubo T, Sahunalu P, Dhanmmanonda P, Nanami S, Yamakura T, Sorn-ngai A. 2009. Intra- and interspecific variation in wood density and fine-scale spatial distribution of stand-level wood density in a northern Thai tropical montane forest. Journal of Tropical Ecology 25: 359-370.

Wolf JHD. 1994. Factors controlling the distribution of vascular and non-vascular epiphytes in the northern Andes. Vegetatio 112: $15-28$

Wolf JHD, Alejandro F-S. 2003. Patterns in species richness and distribution of vascular epiphytes in Chiapas, Mexico. Journal of Biogeography 30: 1689-1707.

Wolf JHD, Gradstein SR, Nadkarni NM. 2009. A protocol for sampling vascular epiphyte richness and abundance. Journal of Tropical Ecology 25: 107-121.

Zhu H. 2004. Biogeographical implications of some plant species from a tropical montane rain forest in Southern Yunnan. Chinese Geographical Science 14: 221-226.

Zotz G, Schultz S. 2008. The vascular epiphytes of a lowland forest in Panama-species composition and spatial structure. Plant Ecology 195: 131-141.

Received: October 2, 2012

Accepted: January 11, 2013 